\title{
PENENTUAN LOKASI ALTERNATIF TEMPAT PEMBUANGAN AKHIR SAMPAH (TPA) MENGGUNAKAN QUANTITATIVE METHOD
}

\author{
Muhammad Zainuddin Fathoni \\ Program Studi Teknik Industri \\ Universitas Muhammadiyah Gresik \\ zainuddin@umg.ac.id
}

\begin{abstract}
Placement and determination of waste landfill locations in each city is very important. The location of a landfill that is not well organized will cause some negative consequences, which can cause damage to infrastructure; local environmental pollution; release of methane gas which is called organic decomposition; means of carrying diseases such as rats and flies; and simple interference. The existing landfill in Gresik city, precisely in the Ngipik Village, needs to be evaluated again because besides being in an urban location, the TPA has already been overloaded. Stakeholders need to find alternative locations to organize the city and make the city more comfortable for residential and urban areas.

The solution to the problem requires a support method to find a solution. One method of supporting the decision is the method of transportation, this method can help to determine the optimal location of various alternatives. The transportation method discusses the distribution of goods from a number of sources (supply) to various destinations (requests) with the aim of minimizing the costs of transportation that occur.

The results of calculating the optimal solution for each location using POM software by using a combination of existing landfill with TPA proposed I total costs spent in a day Rp.1.764.105,20. Temporary costs incurred using the existing landfill combination with TPA proposed II is Rp. 1.981.150,60. And the costs incurred using the existing landfill combination with the TPA proposed I and TPA proposed II amounting to Rp.2.121.919,80. The combination of the use of the existing landfill with TPA proposed I has the lowest cost value of all alternatives.
\end{abstract}

Keywords: final waste disposal place, supply, capacity, transportation.

\section{PENDAHULUAN}

Gaya hidup manusia yang konsumtif dan serba instan banyak dipengaruhi oleh perkembangan teknologi yang semakin maju dan kemegahan zaman. Hal ini memberi tuntutan bagi industri penghasil kebutuhan masyarakat dalam mencukupi kebutuhan tersebut. Di balik itu semua, timbul masalah nyata yaitu bertambahnya jumlah sampah. Semakin maju tingkat penguasaan teknologi, industri dan kebudayaan suatu bangsa, sampah yang dihasilkan diduga semakin banyak (Tatik Khusniah, 2013). Selain itu, pertambahan penduduk dan perubahan pola konsumsi masyarakat menimbulkan bertambahnya volume, jenis, dan karakteristik sampah yang semakin beragam.

Pertambahan jumlah sampah yang tidak diimbangi dengan pengelolaan yang ramah lingkungan akan menyebabkan terjadinya kerusakan dan pencemaran lingkungan. Lahan
TPA tidak mengalami penambahan sedangkan setiap hari sampah terus dihasilkan, akibatnya sampah semakin menumpuk dan meninggi. Disamping itu, sampah yang menumpuk, terutama jenis sampah organik sering membawa beberapa bibit penyakit tanaman, hewan dan manusia serta disukai binatang-binatang sejenis serangga yang dapat mengganggu lingkungan (Yulipriyanto, 2013). Dengan demikian, upaya pengelolaan sampah yang baik memang perlu dilakukan. Pada umumnya, masyarakat kurang peduli dengan sampah. Biasanya sampah hanya dibuang begitu saja tanpa dipilah dan dipisahkan serta dianggap tidak bermanfaat lagi.

Pada saat ini jumlah sampah di Indonesia sebanding dengan tingkat konsumsi manusia terhadap barang atau material yang digunakan sehari-hari, sehingga pengelolaan sampah tidak terlepas dari pengelolaan gaya hidup masyarakat. Sampai saat ini, permasalahan sampah belum 
teratasi dengan baik terutama di perkotaan. Tempat Pembuangan Sementara (TPS) merupakan tempat penampungan pembuangan sampah yang bersifat sementara di kelurahan sebelum diangkut ke Tempat Pembuangan Akhir Sampah (TPA). Minimnya tempat pembuangan sementara (TPS) membuat masyarakat semakin seenaknya dalam membuang sampah. Kenyataan ini juga yang selalu menjadi salah satu penyebab banyaknya masyarakat yang membuang sampah sembarangan.

Kabupaten Gresik memiliki 1 (satu) tempat pembuangan akhir (TPA) sampah yaitu TPA Ngipik yang beroperasi sejak tahun 2002. TPA Ngipik terletak di wilayah Gresik bagian tengah tepatnya di Kelurahan Ngipik, Kecamatan Gresik. Luas lahan TPA Ngipik sebesar 6 ha dengan daya tampung awal sebesar $400 \mathrm{~m}^{3} /$ hari. Dengan semakin meningkatnya timbunan sampah di Kabupaten Gresik dan semakin diperluasnya area pelayanan persampahan, maka timbunan sampah yang masuk ke TPA Ngipik juga semakin bertambah. Timbunan sampah masuk TPA Ngipik pada tahun 2017 mencapai lebih dari $800 \mathrm{~m}^{3} /$ hari. Jumlah tersebut sebesar 2 (dua) kali lipat dari daya tampung awal TPA Ngipik. Saat ini luas lahan yang tersisa untuk zona pembuangan hanya tersisa \pm 1 ha. Apabila tidak terdapat pengurangan jumlah sampah yang masuk dan proses pengolahan sampah maka diperkirakan TPA Ngipik akan mengalami kelebihan kapasitas (overload).

Terdapat penelitian Pratiwi (2016) yang berjudul "Sistem Penunjang Keputusan Penentuan Lokasi Terbaik Pembuangan Sampah Sementara menggunakan Metode Brown Gibson" yaitu suatu aplikasi Sistem Penunjang Keputusan (SPK) untuk menentukan suatu zona kelayakan lokasi tempat pembuangan sampah, metode tersebut merupakan metode yang digunakan untuk penunjang pengambilan keputusan agar dapat dilakukan lebih cepat dan cermat dengan melalui perhitungan kriteriakriteria yang ada. Pada penelitian ini, peneliti menggunakan salah satu metode kuantitatif yaitu metode Transportasi, karena metode ini dapat membantu pengambilan keputusan menentukan lokasi teroptimal dari beberapa lokasi alternatif tempat pembuangan akhir sampah berdasarkan kriteria kuantitatif yang dipertimbangkan. Penentuan lokasi tempat pembuangan akhir sampah dibantu juga dengan visualisasi mapping.
Sesuai dengan latar belakang tersebut, peneliti mengangkat sebuah judul penelitian yaitu "Penentuan Lokasi Alternatif Tempat Pembuangan Akhir Sampah Menggunakan Quantitative Method. Studi Kasus: di Kota Gresik".

\section{Tujuan Penelitian}

1. Mencari nilai solusi optimal tiap alternatif yang digunakan sebagai pengambilan keputusan penentuan tempat pembuangan akhir sampah berdasarkan metode kuantitatif.

2. Menentukan usulan lokasi a lternatif tempat pembuangan akhir sampah yang dapat digunakan oleh stakeholder.

\section{TINJAUAN PUSTAKA}

Perluasan atau ekspansi pabrik / fasilitas adalah suatu hal yang paling sering membawa manajemen kearah persoalan penentuan lokasi (Sritomo Wignjosoebroto, 2009). Menurut Sritomo (2009), suatu industri pada hakikatnya akan memperluas sistem usahanya bilamana:

1. Fasilitas-fasilitas produksi sudah dirasakan jauh dari ketinggalan.

2. Kebutuhan pasar (market demand) tumbuh dan berkembang diluar jangkauan kapasitas produksi yang ada.

3. Service yang tidak mencukupi dan memuaskan konsumen.

Pada dasarnya lokasi fasilitas yang ideal terletak pada suatu tempat yang mampu memberikan total biaya produksi yang rendah dan keuntungan yang maksimal. Penentuan lokasi fasilitas merupakan suatu keputusan yang penting, karena kesalahan yang dibuat sangat berisiko kehilangan investasi yang sudah dikeluarkan.

\section{Dasar-dasar Pemilihan Lokasi Fasilitas}

Langkah yang diambil dalam proses penentuan lokasi fasilitas setidaknya terdapat dua langkah, yaitu pemilihan daerah atau teritorial secara umum dan pemilihan berdasarkan size jumlah penduduk serta lahan secara khusus. Beberapa kondisi umum ikut pula dalam mempengaruhi pengambilan keputusan dalam penentuan lokasi fasilitas, diantaranya:

1. Lokasi di tengah kota

2. Lokasi di pinggir kota

3. Lokasi jauh diluar kota 


\section{Metode-metode Penentuan Alternatif Lokasi Pabrik atau Fasilitas}

Terdapat dua metode pendekatan dalam menentukan alternatif lokasi fasilitas yang sebaiknya dipilih, yaitu metode kualitatif dan metode kuantitatif (Sritomo Wignjosoebroto, 2009).

\section{Alternatif pemilihan lokasi fasilitas dengan metode kualitatif}

Metode ini lebih bersifat kualitatif dan subyektif, aplikasi ini lebih cocok untuk problema-problema yang sulit untuk dikuantitatifkan. Prosedur dalam pendekatan dengan metode kualitatif ini bisa diatur berdasarkan langkah-langkah analisis sebagai berikut:

1. Mengidentifikasi faktor-faktor yang relevan dan memiliki signifikansi yang berkaitan dengan proses pemilihan lokasi fasilitas.

2. Memberi bobot dari masing-masing faktor yang telah diidentifikasikan tersebut berdasarkan derajat kepentingannya (weighted prosedure).

3. Memberi skor (nilai) untuk masing-masing faktor yang diidentifikasikan sesuai dengan skala angka (range berkisar $0 \mathrm{~s} / \mathrm{d} 10$, dengan angka 10 merupakan yang terbaik)

4. Mengalikan bobot dari masing-masing faktor tersebut diatas dengan skor dari tiaptiap alternatif yang ada.

\section{Alternatif pemilihan lokasi fasilitas dengan metode kuantitatif}

Metode ini lebih bersifat kuantitatif dan dianggap obyektif karena penilaiannya akan didasarkan pada ukuran-ukuran yang bisa dikuantitatifkan secara nyata. Metode kuantitatif secara garis besar dibagi menjadi dua metode dasar, yaitu:

- Metode analisis pusat gravitasi (centre of gravity approach).

- Metode analisis transportasi (metode North West Corner Rules, metode heuristic least cost, dan Vogel's approximation method).

\section{Centre of Gravity Approach}

Pendekatan analisis pusat gravitasi dibuat dengan memperhitungkan jarak masing-masing lokasi sumber material dengan lokasi fasilitas yang direncanakan. Disini diasumsikan bahwa biaya produksi atau distribusi untuk masingmasing lokasi akan sama. Lokasi yang optimal dari suatu pusat fasilitas akan dipengaruhi oleh titik lokasi dimana sumber-sumber material / bahan baku yang dibutuhkan berada.

\section{Metode Analisis Transportasi}

Pendekatan analisis transportasi meliputi pemecahan permasalahan-permasalahan seperti:

- Penetapan supply yang cukup untuk beberapa lokasi tujuan dari berbagai sumber tertentu dengan biaya yang minimal.

- Pemilihan lokasi untuk fasilitas baru untuk memenuhi kebutuhan yang akan datang.

- Penetapan berbagai macam bentuk / sumber produksi guna memenuhi kapasitas produksi sesuai dengan demand yang akan datang dan biaya yang minimal.

Penyelesaian masalah dengan metode transportasi dapat direpresentasikan secara skematis pada gambar 1 (Sritomo Wignjosoebroto, 2009) 


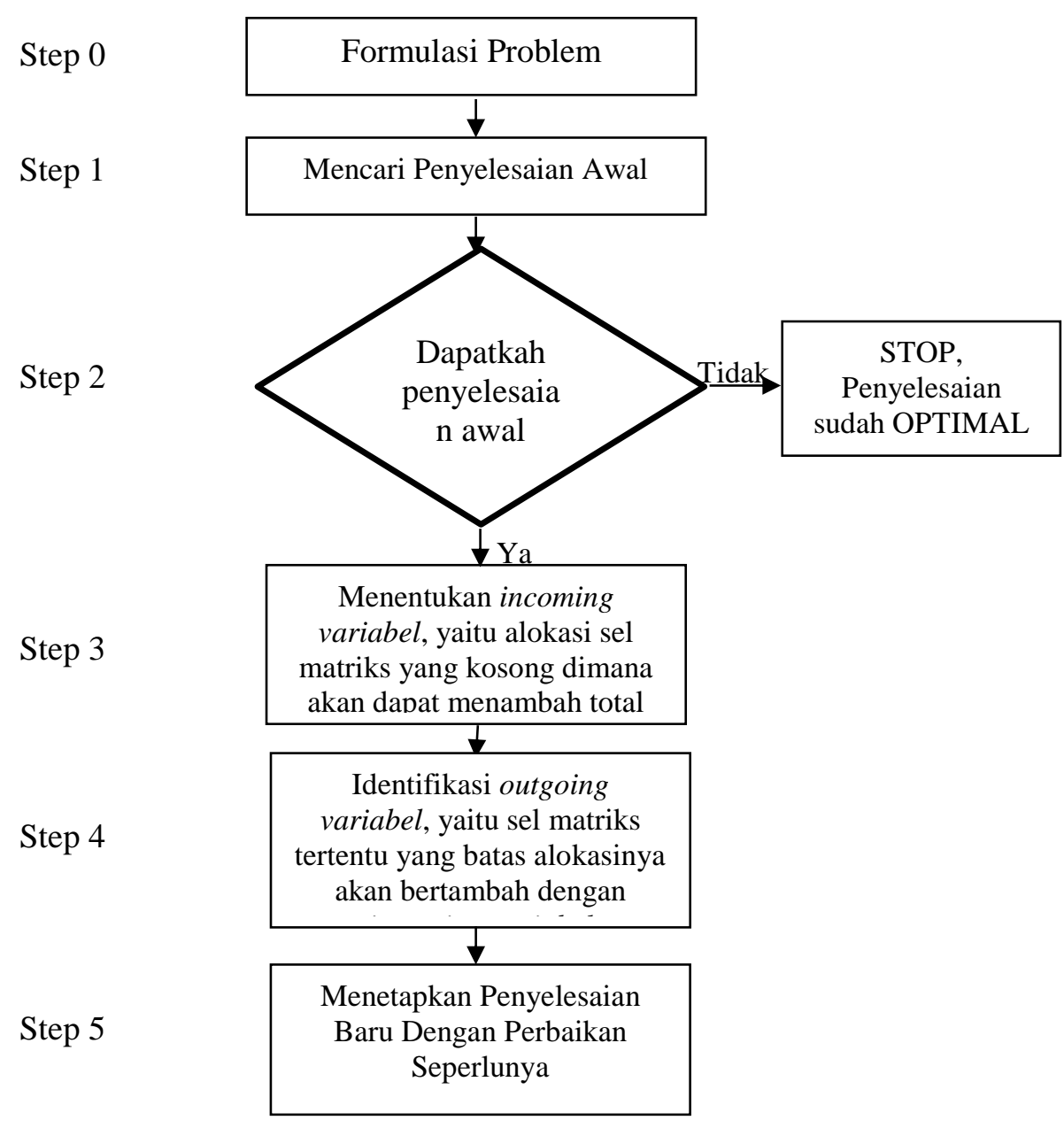

Gambar 1. Flow Chart Penyelesaian Masalah dengan Metode Analisis Transportasi

Penjelasan prosedur penyelesaian masalah transportasi dibahas melalui tahapantahapan berikut :

Langkah 0 : Penyelesaian formulasi problem Pada tahap formulasi problem ini perlu diperhatikan apakah sudah seimbang antara total supply dengan total demand dari masing-masing lokasi tujuan. Apabila tidak seimbang, maka perlu dibuat data "dummy" yang sesuai.

Langkah 1 : Penyelesaian awal

Pada tahap ini bisa dilakukan dengan aplikasi salah satu metode, yaitu metode heuristic, metode North-West Corner Rules, dan Vogel's approximation method.

Penyelesaian awal ini memerlukan 3 kondisi yang harus dipenuhi, yaitu :

- Penyelesaian dalam bentuk pengalokasian harus memenuhi kelayakan (feasible) yaitu sesuai dengan batasan supply dan demand yang ada.

- Alokasi harus menempati seluruh matrix sel yang ada dan memenuhi persyaratan $\mathrm{m}+\mathrm{n}-$ 1 (jumlah seluruh batasan sumber supplies dan kebutuhan lokasi tujuan).

- Alokasi sel matrix pada posisi yang tidak membentuk lintasan tertutup (closed path)

Langkah 2 : Evaluasi penyelesaian awal

- Identifikasi sel matrix yang terisi pada posisi pojok yang menghasilkan unique closed path yang akan dipengaruhi oleh alokasi percobaan ini.

- Tetapkan macam alokasi penyelesaian yang diperlukan untuk tetap menjaga kemungkinan penyelesaian. Ini meliputi langkah-langkah penambahan atau pengurangan 1 unit pada sel-sel yang terisi. 
- Ukur perubahan biaya yang disebabkan oleh alokasi penyesuaian ini.

- Hitung efek perubahan biaya yang menggambarkan apakah perbaikan yang ingin dilakukan bisa terjadi.

Langkah 3 : Menentukan incoming variable (Pengalokasian sel matriks kosong)

Langkah 4 : Identifikasi outgoing variable (Realokasi sel matriks untuk solusi baru)

Langkah 5 : Penentapan solusi terbaru.

\section{Penyusunan Metode Transportasi}

Persoalan transportasi membahas pendistribusian suatu komoditas (barang) dari sejumlah sumber (supply) kepada sejumlah tujuan (demand), dengan tujuan meminimumkan ongkos pengangkutan yang terjadi. Ciri-ciri khusus persoalan transportasi ini adalah:

1. Terdapat sejumlah sumber dan sejumlah tujuan tertentu.

2. Kuantitas komoditas yang didistribusikan dari setiap sumber dan yang diterima oleh setiap tujuan, besarnya tertentu.

3. Komoditas yang dikirim atau diangkut dari suatu sumber ke suatu tujuan, besarnya sesuai dengan permintaan dan atau kapasitas sumber.
4. Ongkos pengangkutan komoditas dari suatu sumber ke suatu tujuan, besarnya tertentu.

Secara diagramatik, model transportasi dapat digambarkan misalkan ada $\mathrm{m}$ buah sumber dan $\mathrm{n}$ buah tujuan.

Masing-masing sumber mempunyai kapasitas ai, $\mathrm{i}=1,2,3, \ldots \mathrm{m}$.

Masing-masing tujuan membutuhkan komoditas sebanyak bj, $\mathrm{j}=1,2,3, \ldots \mathrm{n}$.

Jumlah satuan yang dikirim dari sumber i ke tujuan $\mathrm{j}$ adalah sebanyak Xij.

Ongkos pengiriman perunit dari sumber i ke tujuan $\mathrm{j}$ adalah $\mathrm{Cij}$.

Dengan demikian, maka formulasi programa liniernya sebagai berikut: (Taylor, 2006)

Minimumkan: $z=\sum_{i=1}^{m} \sum_{j=1}^{n} c_{i j} x_{i j}$

Berdasarkan pembatas:

$$
\begin{aligned}
& \sum_{j=1}^{n} x_{i j}=a_{i}, i=1,2, \ldots, \quad m \\
& \sum_{i=1}^{m} x_{i j}=b_{j}, \quad i=1,2, \ldots, \quad n \\
& x_{i j} \geq 0 \text { untuk seluruh } i \text { dan } j
\end{aligned}
$$




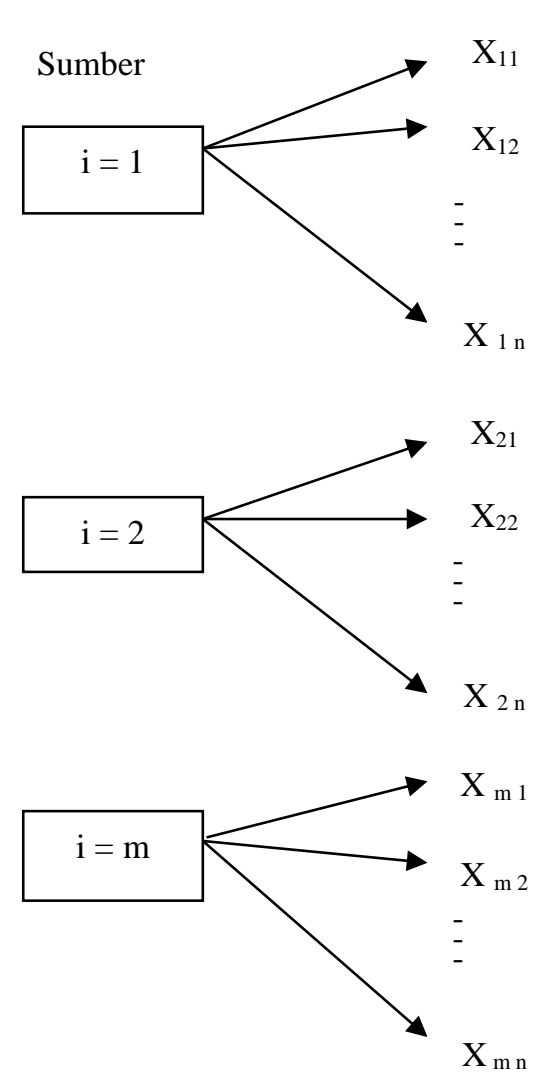

Tujuan

b

$\mathrm{j}=1$

$\mathrm{j}=2$

$j=3$

Gambar 2. Gambar Diagramatik Model Transportasi

Minimumkan:

$\mathrm{Z}=\mathrm{c}_{11} \mathrm{X}_{11}+\mathrm{c}_{12} \mathrm{X}_{12}+\mathrm{c}_{13} \mathrm{X}_{13}+\mathrm{c}_{21} \mathrm{X}_{21}+\mathrm{c}_{22} \mathrm{X}_{22}+\mathrm{c}_{23} \mathrm{X}_{23}$

$+\mathrm{c}_{\mathrm{im}} \mathrm{X}_{\mathrm{jn}}$

Berdasarkan pembatas:

$\begin{array}{ll}\mathrm{x}_{11}+\mathrm{x}_{12}+\mathrm{x}_{13} & =\mathrm{a}_{1} \\ \mathrm{x}_{21}+\mathrm{x}_{22}+\mathrm{x}_{23} & =\mathrm{a}_{2} \\ \mathrm{x}_{11}+\mathrm{x}_{21} & =\mathrm{b}_{1} \\ \mathrm{x}_{12}+\mathrm{x}_{22} & =\mathrm{b}_{2} \\ \mathrm{x}_{13}+\mathrm{x}_{23} & =\mathrm{b}_{3} \\ \quad \text { Suatu model } & \text { transportasi dikatakan }\end{array}$ seimbang apabila total supply sama dengan total demand. Dengan kata lain:

$$
\sum_{i=1}^{m} a_{i}=\sum_{j=1}^{n} b_{j}
$$

Jika jumlah demand melebihi jumlah supply, maka dibuat suatu sumber dummy yang akan men-supply kekurangan tersebut, yaitu sebanyak $\sum$ bj - $\sum$ ai. Sebaliknya, jika jumlah supply melebihi jumlah demand, maka dibuat suatu tujuan dummy untuk menyerap kelebihan tersebut, yaitu sebanyak $\sum \mathrm{i}$ ai $-\sum \mathrm{j}$ bj.
Ongkos transportasi per unit (Cij) dari sumber dummy ke seluruh tujuan adalah nol. Hal ini dapat dipahami karena pada kenyataannya dari sumber dummy tidak terjadi pengiriman. Begitu pula ongkos transportasi perunit (Cij) dari semua sumber ke tujuan dummy adalah nol (Fathoni, 2013).

\section{METODOLOGI PENELITIAN}

Gambaran tentang langkah-langkah pemecahan masalah dalam penelitian ini dibuat melalui beberapa tahap. Pada masing-masing tahap akan terdiri dari beberapa kagiatan penelitian yang saling berkaitan satu sama lain. Secara umum tahapan-tahapan selama penelitian dijabarkan dalam diagram alir penelitian.

\section{Diagram Alir Penelitian}

Diagram alir penelitian ini dimaksudkan untuk memudahkan langkah-langkah yang dilakukan dalam melakukan penelitian, dapat digambarkan seperti pada Gambar 3. 


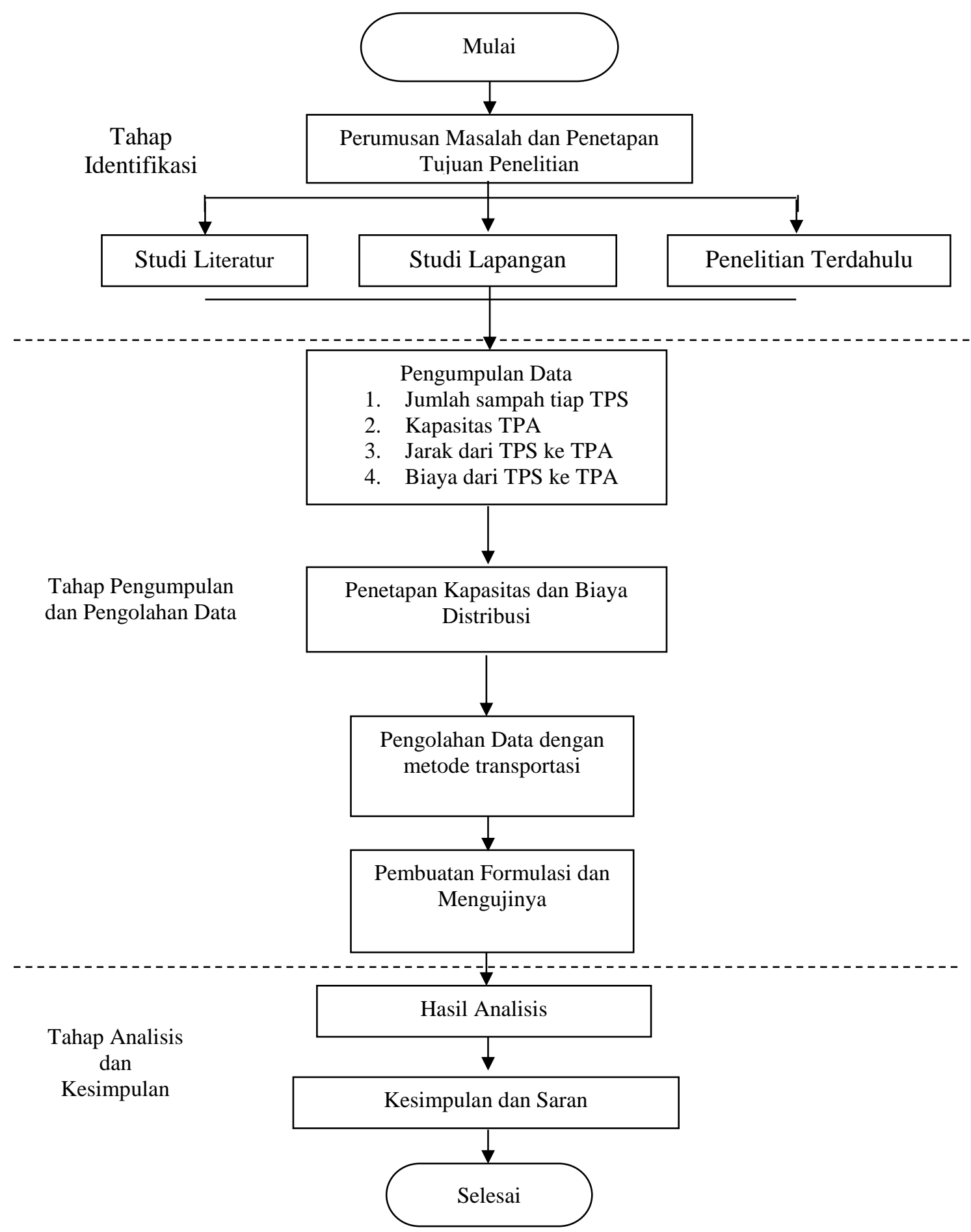

Gambar 3. Diagram Alir Penelitian

\section{PENGUMPULAN DAN PENGOLAHAN} DATA

Data-data yang dikumpulkan sangat mendukung dalam pemecahan suatu permasalahan yang berhubungan dengan kebijakan penentuan lokasi alternatif tempat pembuangan akhir sampah (TPA).

\section{Pemrosesan Akhir (TPA) Ngipik}

TPA Ngipik terletak di Kelurahan Ngipik, Kecamatan Gresik. TPA tersebut mulai beroperasi sejak tahun 2002. Luas lahan TPA 
Ngipik sebesar 6 ha dengan zona pembuangan sebesar 4 ha. Sisa lahan digunakan untuk sarana dan prasarana penunjang TPA. Terdapat rencana perluasan lahan TPA sebesar 3,5 ha. Status lahan TPA Ngipik bukan milik Pemerintah Kabupaten Gresik, akan tetapi merupakan lahan pinjam pakai milik PT. Semen Gresik.

Total volume sampah masuk ke TPA Ngipik hingga akhir tahun 2016 sebesar $291.706 \mathrm{~m}^{3}$ (87.511 ton) dengan timbulan sampah sebesar $797 \mathrm{~m}^{3}$ per hari. Sementara pada tahun 2017 (hingga bulan Mei), timbulan sampah yang masuk ke TPA telah mencapai $117.297 \mathrm{~m}^{3}(40 \%$ dari total volume sampah tahun 2016).

\section{Daya tampung / angkut sampah tiap TPS}

Tabel 1. Jumlah tampung angkut sampah tiap TPS

\begin{tabular}{|c|l|r|r|}
\hline \multicolumn{2}{|l|}{ Kecamatan } & $\begin{array}{l}\text { jumlah } \\
\text { TPS }\end{array}$ & $\begin{array}{l}\text { volume } \\
(\mathrm{m} 3)\end{array}$ \\
\hline 1 & Balong panggang & 1 & 6,000 \\
\hline 2 & Benjeng & 3 & 13,998 \\
\hline 3 & Bungah & 3 & 9,000 \\
\hline 4 & Cerme & 13 & 49,000 \\
\hline 5 & Driyorejo & 5 & 23,000 \\
\hline 6 & Duduk sampeyan & 9 & 23,992 \\
\hline 7 & Dukun & 3 & 9,000 \\
\hline 8 & Gresik & 16 & 261,000 \\
\hline 9 & Kebomas & 40 & 269,670 \\
\hline 10 & Kedamean & 1 & 3,000 \\
\hline 11 & Manyar & 16 & 117,998 \\
\hline 12 & Menganti & 8 & 27,996 \\
\hline 13 & Panceng & 2 & 3,000 \\
\hline 14 & Sangkapura* & - & - \\
\hline 15 & Sidayu & 3 & 18,000 \\
\hline 16 & Tambak* & - & - \\
\hline 17 & Ujung pangkah & 1 & 2,000 \\
\hline 18 & Wringin anom & 1 & 2,000 \\
\hline
\end{tabular}

Sumber : DLH Gresik 2017

(* Pengelolaan dilakukan swadaya)

\section{Kapasitas TPA}

Berdasarkan laporan studi revitalisasi TPA Ngipik bahwa timbulan sampah perhari adalah $800 \mathrm{~m} 3 /$ hari, padahal daya tampung awal TPA Ngipik adalah $400 \mathrm{~m} 3 /$ hari (Studi revitalisasi, p. I-1). Kapasitas TPA usulan berdasarkan estimasi daya tampung perhari dimana TPA usulan I sebesar $330 \mathrm{~m} 3 /$ hari (studi kelayakan TPA Banyutengah Panceng, 2013, p.47-51). Kapasitas TPA usulan II sebesar $371 \mathrm{~m} 3 / \mathrm{hari}$ (studi kelayakan TPA Lebanisuko Wringinanom, 2012, p.47 \& 93) dengan estimasi umur pakai berjenjang.

\section{Jarak TPS Kecamatan dengan TPA}

Dalam menentukan jarak antara tiap TPS dengan TPA Ngipik dan TPA usulan menggunakan jalur transportasi berbasis google map. Hasil rekapitulasi jarak nya seperti terlihat pada tabel 2.

Tabel 2. Jarak tiap TPS Kecamatan dengan TPA Ngipik dan TPA usulan

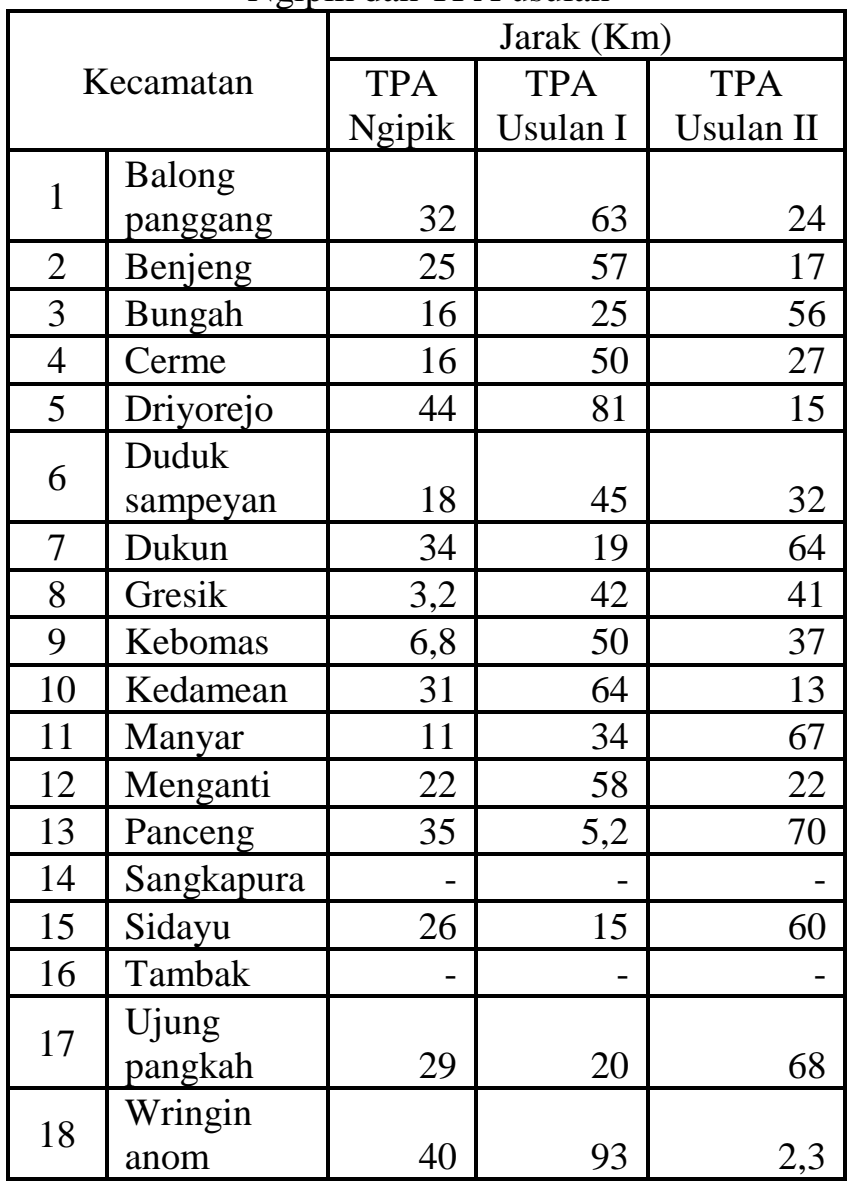

Sumber : Diolah

\section{Biaya dari TPS Kecamatan Menuju TPA}

Dalam menentukan biaya, peneliti hanya memasukkan unsur biaya distribusi dari TPS ke TPA existing dan TPA usulan dengan menggunakan perhitungan perkalian antara jarak dengan harga solar. Rincian perhitungan biaya sebagai berikut:

- Harga solar Rp. 5.150, berdasarkan wawancara dengan pihak terkait untuk 1 liter solar bisa dibuat kendaraan untuk menempuh jarak $6 \mathrm{Km}$. Sehingga biaya transportasi per Km adalah Rp. 5.150 dibagi 6 Km menjadi Rp. 858/Km 
- Standard ritasi dalam sekali perjalanan, kendaraan mampu mengangkut sampah sebanyak $6 \mathrm{~m}^{3}$. Maka biaya per $\mathrm{m}^{3}$ adalah Rp. $858: 6 \mathrm{~m}^{3}=$ Rp. $143 / \mathrm{Km} \cdot \mathrm{m}^{3}$

Contoh perhitungan biaya distribusi sampah per- $\mathrm{m}^{3}$ dari TPS Kecamatan Balong panggang ke TPA Ngipik adalah jarak $32 \mathrm{Km}$ dikalikan biaya per- $\mathrm{m}^{3}$ Rp. $143 / \mathrm{m}^{3}$ yaitu sebesar Rp. 4765. Detail biaya dari TPS ke TPA Ngipik dan TPA usulan seperti terlihat pada tabel 3 .

Tabel 3. Biaya angkut dari TPS ke TPA Ngipik dan TPA usulan

\begin{tabular}{|r|l|r|r|r|}
\hline \multirow{2}{*}{ Kecamatan } & \multicolumn{3}{|c|}{ Biaya distribusi per m3 (Rp.) } \\
\cline { 3 - 5 } \multicolumn{2}{|c|}{$\begin{array}{c}\text { TPA } \\
\text { Ngipik }\end{array}$} & $\begin{array}{c}\text { TPA } \\
\text { usulan I }\end{array}$ & $\begin{array}{c}\text { TPA } \\
\text { Usulan II }\end{array}$ \\
\hline 1 & $\begin{array}{l}\text { Balong } \\
\text { panggang }\end{array}$ & 4576,0 & 9009,0 & 3432,0 \\
\hline 2 & Benjeng & 3575,0 & 8151,0 & 2431,0 \\
\hline 3 & Bungah & 2288,0 & 3575,0 & 8008,0 \\
\hline 4 & Cerme & 2288,0 & 7150,0 & 3861,0 \\
\hline 5 & Driyorejo & 6292,0 & 11583,0 & 2145,0 \\
\hline 6 & $\begin{array}{l}\text { Duduk } \\
\text { sampeyan }\end{array}$ & 2574,0 & 6435,0 & 4576,0 \\
\hline 7 & Dukun & 4862,0 & 2717,0 & 9152,0 \\
\hline 8 & Gresik & 457,6 & 6006,0 & 5863,0 \\
\hline 9 & Kebomas & 972,4 & 7150,0 & 5291,0 \\
\hline 10 & Kedamean & 4433,0 & 9152,0 & 1859,0 \\
\hline 11 & Manyar & 1573,0 & 4862,0 & 9581,0 \\
\hline 12 & Menganti & 3146,0 & 8294,0 & 3146,0 \\
\hline 13 & Panceng & 5005,0 & 743,6 & 10010,0 \\
\hline 14 & Sangkapura & 0,0 & 0,0 & 0,0 \\
\hline 15 & Sidayu & 3718,0 & 2145,0 & 8580,0 \\
\hline 16 & Tambak & 0,0 & 0,0 & 0,0 \\
\hline 17 & $\begin{array}{l}\text { Ujung } \\
\text { pangkah }\end{array}$ & 4147,0 & 2860,0 & 9724,0 \\
\hline 18 & $\begin{array}{l}\text { Wringin } \\
\text { anom }\end{array}$ & 5720,0 & 13299,0 & 328,9 \\
\hline Suny & $6 e r$ Dion & & & \\
\hline
\end{tabular}

Sumber : Diolah

\section{Pengolahan Data Menggunakan Metode Transportasi}

Setelah semua data yang diperlukan untuk menganalisis terkumpul, maka selanjutnya adalah memasukkan data tersebut kedalam formulasi metode transportasi seperti terlihat pada tabel 4. Cara mendapatkan solusi optimal bisa juga menggunakan aplikasi software POM, namun output dari software ini tidak menunjukkan proses iterasi (Mulyono, 2002).

Tabel 4. Formulasi awal metode Transportasi

\begin{tabular}{|c|c|c|c|c|c|}
\hline \multirow{2}{*}{ Dari } & \multirow{3}{*}{ 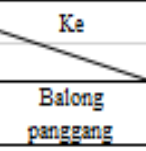 } & \multicolumn{3}{|c|}{ TPA (m3/hari) } & \multirow{2}{*}{$\frac{\text { Supply (m3/hari) }}{\left(\mathrm{a}_{\mathrm{l}}\right)}$} \\
\hline & & Ngipik & Usulan I & Usulan II & \\
\hline \multirow{21}{*}{\begin{tabular}{l}
$\alpha$ \\
\multicolumn{1}{c}{} \\
$m$ \\
$m$ \\
$\Sigma$ \\
$\square$ \\
$\square$
\end{tabular}} & & 4576 & 9009 & 3432 & 6 \\
\hline & Benjeng & 3575 & 8151 & 2431 & 14 \\
\hline & Bungah & 2288 & 3575 & 8008 & 9 \\
\hline & Cerme & 2288 & 7150 & 3861 & 49 \\
\hline & Driyorejo & 6292 & 11583 & 2145 & 23 \\
\hline & Duduk & 2574 & 6435 & 4576 & \multirow[t]{2}{*}{24} \\
\hline & Sampeyan & 4802 & 271 & 952 & \\
\hline & Dokun & & & & 9 \\
\hline & Gresik & 457,6 & 6006 & 5863 & 261 \\
\hline & Kebomas & 972,4 & 7150 & 5291 & 270 \\
\hline & Kedamean & 4433 & 9152 & 1859 & 3 \\
\hline & Manyar & 1573 & 4862 & 9581 & 118 \\
\hline & Menganti & 3146 & 8294 & 3146 & 28 \\
\hline & \multirow{2}{*}{ Panceng } & 5005 & 743,6 & 10010 & \multirow{2}{*}{3} \\
\hline & & & & & \\
\hline & Sangkapura & & & & \\
\hline & Sidayu & 3718 & 2145 & 8580 & 18 \\
\hline & Tambak: & & & & \\
\hline & \multirow{2}{*}{ Ujungpangkah } & 4147 & 2860 & 9724 & 2 \\
\hline & & & & & \\
\hline & Wringinanom & 5720 & 13299 & 328,9 & 2 \\
\hline & pacity (bj) & 400,00 & 287,03 & 371,00 & \\
\hline
\end{tabular}

Hasil perhitungan menunjukkan bahwa apabila menggunakan kombinasi TPA existing dengan TPA usulan I total biaya yang dikeluarkan dalam sehari Rp.1.764.105,20 seperti terlihat pada tabel 5 .

Sementara biaya yang dikeluarkan apabila menggunakan kombinasi TPA existing dengan TPA usulan II adalah sebesar Rp. 1.981.150,60 seperti terlihat pada tabel 6 .

Dan biaya yang dikeluarkan apabila menggunakan kombinasi TPA existing dengan TPA usulan I dan TPA usulan II adalah sebesar Rp.2.121.919,80 seperti terlihat pada tabel 7 . 
Tabel 5. Hasil Kombinasi TPA existing dengan TPA usulan I

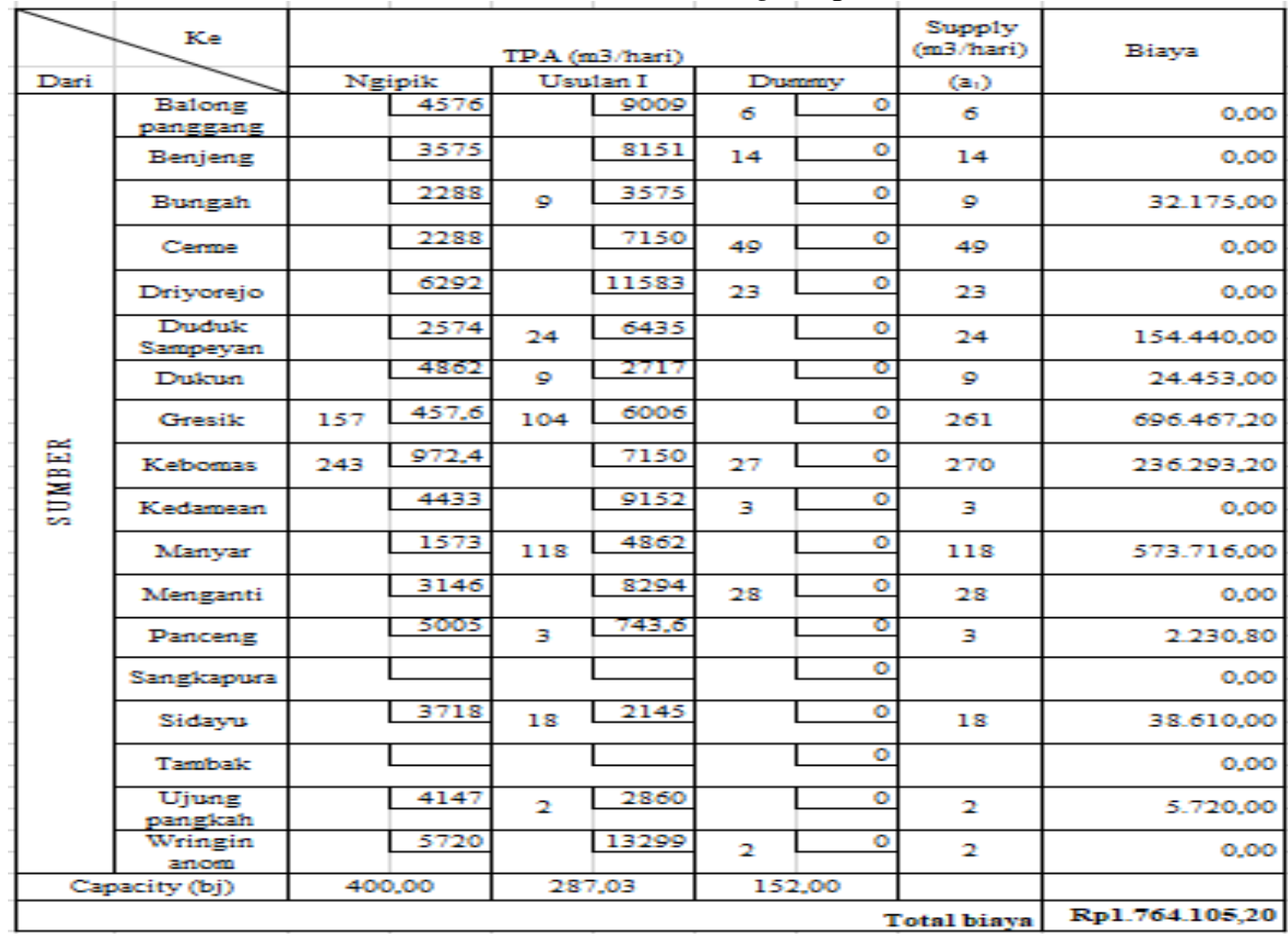

Tabel 6. Hasil Kombinasi TPA existing dengan TPA usulan II

\begin{tabular}{|c|c|c|c|c|c|c|}
\hline \multirow{2}{*}{ Dari } & \multirow{3}{*}{$\underbrace{}_{\substack{\text { Elalong } \\
\text { pangeang }}}$} & \multicolumn{3}{|c|}{ TPA (m3/hari) } & $\begin{array}{l}\text { Supply } \\
\text { (min3/hari }\end{array}$ & \multirow[t]{2}{*}{ Eiaya } \\
\hline & & Ngipil: & Travilan II & Drummy & $\left(\mathbf{a}_{1}\right)$ & \\
\hline \multirow{18}{*}{$\underset{⿱ ㇒}{E}$} & & 4456 & $6 \quad 3432$ & & 6 & $20.592,00$ \\
\hline & Eenji=ng & 3575 & \begin{tabular}{l|l|}
14 & 2431 \\
\cline { 2 - 2 }
\end{tabular} & & 14 & 34.034 .000 \\
\hline & Bungah & $22 \mathrm{ag}$ & Doog: & 9 & 9 & 0.00 \\
\hline & Cerme & $22 \mathrm{ag}$ & 49 D.61 & & 49 & 199.190 .00 \\
\hline & Driyourejo & 6292 & $23 \quad 2145$ & & 23 & 49.335 .00 \\
\hline & $\begin{array}{c}\text { Dodvi: } \\
\text { Sampeyan }\end{array}$ & 2574 & $24 \quad 4576$ & & 24 & $100.824,00$ \\
\hline & Drulawn & $4+862$ & L152 & 9 & 9 & 0.00 \\
\hline & Gresilz & $201 \mathrm{LSg}$ & 5003 & & 261 & $119.433,00$ \\
\hline & Kebomas: & $4 \mathrm{a} \quad \mathrm{g} 2$ & $202 \quad 5291$ & & 270 & $1.221 .277,20$ \\
\hline & Fodamean & 4433 & 3 1259 & & 3 & $=-7.90$ \\
\hline & Mianyar & $91 \quad 1573$ & psa1 & 27 & $11 \mathrm{a}$ & 143.143 .00 \\
\hline & MIEnganti & 3146 & 20 : 3146 & & 28 & ag. $0 \mathrm{ga} .00$ \\
\hline & Panceng & 50005 & 10010 & 3 & 3 & 0.00 \\
\hline & Sanglapura & & & & & 0.00 \\
\hline & Sidayn & 3718 & DSBO & $1 \mathrm{a}$ & $1 \mathrm{a}$ & 0,00 \\
\hline & Tambal: & & & & & 0.90 \\
\hline & $\begin{array}{c}\text { Trjung } \\
\text { pang } 1 \mathrm{jah}\end{array}$ & 4147 & 9724 & $2 L$ & 2 & 0.00 \\
\hline & $\begin{array}{l}\text { Wringin } \\
\text { anom }\end{array}$ & 5720 & $2 \quad 32 \mathrm{a}, 9$ & & 2 & 657,80 \\
\hline \multicolumn{2}{|c|}{ Capacity (bid } & 400,00 & 371,00 & $60 ; 00$ & & Rpil.9sil $1=0,60$ \\
\hline
\end{tabular}


Tabel 7. Hasil Kombinasi TPA existing dengan TPA usulan I dan TPA usulan II

\begin{tabular}{|c|c|c|c|c|c|c|c|c|c|}
\hline \multirow[b]{2}{*}{ Deri } & $\mathrm{F}=$ & \multicolumn{6}{|c|}{ IPA (mis/hari) } & \multirow{2}{*}{$\begin{array}{l}\text { Supply } \\
\text { (ma/hari) } \\
\left(a_{1}\right)\end{array}$} & \multirow[t]{2}{*}{ Eiaya } \\
\hline & & & iitz & $\tau=0$ & $\operatorname{an} I$ & $\tau T=u$ & $\operatorname{lan}$ III & & \\
\hline \multirow{19}{*}{ 焉 } & $\begin{array}{c}\text { Blalong } \\
\text { pengengeng }\end{array}$ & & 4576 & & 90009 & 6 & 3432 & 6 & $20,592,00$ \\
\hline & Eenjeng & & 3575 & & $\mathbb{E} 1 \leq 1$ & 14 & 2431 & 14 & $34.034,00$ \\
\hline & Bungah & & $22 \mathbb{E}$ & 9 & 3575 & & BOOD & 9 & 32175,00 \\
\hline & Cerme & & $22 \mathrm{ag}$ & & 7150 & 49 & $3 \mathbb{B S 1}$ & 49 & 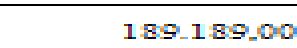 \\
\hline & Drimorejo & & 6292 & & $115 \mathrm{ag}$ & 23 & 2145 & 23 & 49335,00 \\
\hline & $\begin{array}{l}\text { Duduit: } \\
\text { Sempeyran }\end{array}$ & & 2574 & & 6435 & 24 & 4576 & 24 & $109.824,00$ \\
\hline & Dukann & & 4862 & 9 & 2717 & & 9152 & 9 & $24,453,00$ \\
\hline & Gresile & 261 & 457,6 & & soos & & 5669 & 261 & 119.433 .60 \\
\hline & Kebomas & 139 & 9724 & & 7150 & $1 \exists 1$ & 5291 & 270 & $\operatorname{gag} 2 \mathrm{~g} 4,60$ \\
\hline & Kedtamean & & 4433 & & 9152 & 3 & $1 \cos$ & 3 & 5.57700 \\
\hline & MLanyar & & 1573 & $11 \mathbb{E}$ & 4962 & & S5E1 & $11 \mathbb{E}$ & 573716,00 \\
\hline & Mrenganti. & & $\exists 146$ & & B294 & 28 & 3146 & $2 \pi$ & aglogajoo \\
\hline & Pianceng & & 3005 & $\exists$ & 743,6 & & \begin{tabular}{|l|l|}
10010 \\
\end{tabular} & $\exists$ & 2230.80 \\
\hline & Sanglapura & & & & & & L & & 0,00 \\
\hline & Sid=y̆u & & $\exists 71 \mathrm{E}$ & $1 \mathbb{E}$ & 2145 & & BSDO & $1 \mathbb{8}$ & $3 \mathrm{~B} 610,00$ \\
\hline & $T=-n b=12$ & & & & & & & & 0,00 \\
\hline & $\begin{array}{l}\text { Ujumg } \\
\text { pangleah }\end{array}$ & & 4147 & 2 & 2.060 & & 9724 & 2 & 5720,00 \\
\hline & $\begin{array}{l}\text { Wringin } \\
\text { anden }\end{array}$ & & 5720 & & 13299 & 2 & 3289 & 2 & $657 \mathrm{BOO}$ \\
\hline & dumeny & & i & 128,00 & i & 91 1.00 & is & 219,00 & 0,00 \\
\hline$c \equiv$ & pacity (bj) & 40 & $\infty$ & $2 \mathrm{a}:-3 \cdot(-1)$ & os & 371 & $1, \infty$ & & Rp 2121919.50 \\
\hline
\end{tabular}

\section{ANALISIS DAN INTERPRETASI \\ Kondisi Wilayah}

Sebagian besar tanah di wilayah Kabupaten Gresik terdiri dari jenis Aluvial, Grumusol, Mediteran Merah dan Litosol. Berdasarkan ciriciri fisik tanahnya, Kabupaten Gresik dapat dibagi menjadi empat bagian yaitu:

a. Kabupaten Gresik bagian Utara (meliputi wilayah: Panceng, Ujungpangkah, Sidayu, Bungah, Dukun, Manyar) adalah bagian dari daerah pegunungan Kapur Utara yang memiliki tanah relatif kurang subur (wilayah Kecamatan Panceng). Daerah ini sangat potensial karena mampu menciptakan lahan yang cocok untuk industri, perikanan, perkebunan, dan permukiman.

b. Kabupaten Gresik bagian Tengah (meliputi wilayah: Duduk sampeyan, Balong panggang, Benjeng, Cerme, Gresik, Kebomas) merupakan kawasan dengan tanah relatif subur. Wilayah ini merupakan daerah yang cocok untuk pertanian dan perikanan. c. Kabupaten Gresik bagian Selatan (meliputi wilayah: Menganti, Kedamean, Driyorejo dan Wringinanom). Sebagian wilayah merupakan dataran rendah yang cukup subur dan sebagian sisanya merupakan daerah berbukit. Oleh karena itu Kabupaten Gresik Selatan merupakan daerah yang cocok untuk industri, permukiman dan pertanian.

d. Wilayah kepulauan Kabupaten Gresik (meliputi wilayah: Sangkapura dan Tambak) merupakan sebagian dataran rendah yang cukup subur dengan jenis tanah mediteran coklat kemerahan dan sebagian merupakan daerah berbukit sehingga dibagian wilayah ini merupakan daerah yang cocok untuk pertanian, pariwisata, dan perikanan.

Dari beberapa pembagian wilayah di Kabupaten Gresik ini, untuk wilayah kepulauan yaitu kecamatan Sangkapura dan Tambak, proses pengelolaan sampah nya dilakukan sendiri (swadaya) dikarenakan proses distribusi nya yang jauh dan melewati laut. 


\section{Analisis menggunakan kombinasi TPA existing dengan TPA usulan I}

Hasil running software POM menunjukkan bahwa apabila menggunakan kombinasi TPA existing dengan TPA usulan I total biaya yang dikeluarkan dalam sehari Rp.1.764.105,20. Namun terdapat tujuan dummy yaitu sampah yang bersumber dari kecamatan balongpanggang sebanyak $6 \mathrm{~m}^{3}$, dari kecamatan benjeng sebanyak $14 \mathrm{~m}^{3}$, dari kecamatan cerme sebanyak $49 \mathrm{~m}^{3}$, dari kecamatan driyorejo sebanyak $23 \mathrm{~m}^{3}$, dari kecamatan kebomas sebanyak $27 \mathrm{~m}^{3}$, kecamatan kedamean sebanyak $3 \mathrm{~m}^{3}$, dari kecamatan menganti sebanyak $28 \mathrm{~m}^{3}$, dan dari kecamatan wringinanom sebanyak $2 \mathrm{~m}^{3}$ seperti terlihat pada gambar 4. Hal ini menunjukkan apabila menggunakan TPA usulan I pihak dinas terkait tetap perlu memikirkan solusi untuk menampung sampah dari kecamatan-kecamatan tersebut sebanyak total $152 \mathrm{~m}^{3}$.

\begin{tabular}{|c|c|c|c|}
\hline \multicolumn{2}{|c|}{ ton Transportation Shipments } & \multicolumn{2}{|c|}{ 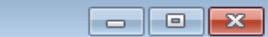 } \\
\hline \multicolumn{4}{|c|}{ (untitled) Solution } \\
\hline $\begin{array}{l}\text { Optimal cost }= \\
\$ 1764105,0\end{array}$ & TPA Existing & TPA usulan I & Dummy \\
\hline Source 1 & & & 6 | \\
\hline Source 2 & & & 14 \\
\hline Source 3 & & 9 & \\
\hline Source 4 & & & 49 \\
\hline Source 5 & & & 23 \\
\hline Source 6 & & 24 & \\
\hline Source 7 & & 9 & \\
\hline Source 8 & 157 & 104 & \\
\hline Source 9 & 243 & & 27 \\
\hline Source 10 & & & 3 \\
\hline Source 11 & & 118 & \\
\hline Source 12 & & & 28 \\
\hline Source 13 & & 3 & \\
\hline Source 14 & & 0 & \\
\hline Source 15 & & 18 & \\
\hline Source 16 & & 0 & \\
\hline Source 17 & & 2 & \\
\hline Source 18 & & & 2 \\
\hline
\end{tabular}

Gambar 4. Hasil running software kombinasi TPA existing dengan TPA usulan I

\section{Analisis menggunakan kombinasi TPA existing dengan TPA usulan II}

Biaya yang dikeluarkan apabila menggunakan kombinasi TPA existing dengan TPA usulan II adalah sebesar Rp. 1.981.150,60. Namun terdapat tujuan dummy seperti terlihat pada gambar 5, yaitu sampah yang bersumber dari kecamatan Bungah sebanyak $9 \mathrm{~m}^{3}$, dari kecamatan Dukun sebanyak $9 \mathrm{~m}^{3}$, dari kecamatan Manyar sebanyak $27 \mathrm{~m}^{3}$, dari kecamatan Panceng sebanyak $3 \mathrm{~m}^{3}$, dari kecamatan Sidayu sebanyak $18 \mathrm{~m}^{3}$ dan dari kecamatan Ujung pangkah sebanyak $2 \mathrm{~m}^{3}$. Hal ini menunjukkan apabila menggunakan TPA usulan II, pihak dinas terkait juga tetap perlu memikirkan solusi untuk menampung sampah dari kecamatan Bungah, Dukun, Manyar, Panceng, Sidayu dan kecamatan Ujung pangkah tersebut sebanyak total $68 \mathrm{~m}^{3}$.

\begin{tabular}{|c|c|c|c|c|}
\hline \multicolumn{3}{|c|}{ Wransportation Shipments } & 0 回 & $x$ \\
\hline \multicolumn{5}{|c|}{ (untitled) Solution } \\
\hline $\begin{array}{l}\text { Optimal cost = } \\
\$ 1981151,0\end{array}$ & TPA Existing & TPA usulan 2 & Dummy & \\
\hline Source 1 & & 6 & & \\
\hline Source 2 & & 14 & & \\
\hline Source 3 & & & 9 & \\
\hline Source 4 & & 49 & & \\
\hline Source 5 & & 23 & & \\
\hline \begin{tabular}{|l|} 
Source 6 \\
\end{tabular} & & 24 & & \\
\hline Source 7 & & & 9 & \\
\hline Source 8 & 261 & & & \\
\hline Source 9 & 48 & 222 & & \\
\hline Source 10 & & 3 & & \\
\hline Source 11 & 91 & & 27 & \\
\hline Source 12 & & 28 & & \\
\hline Source 13 & & & 3 & \\
\hline \begin{tabular}{|l|} 
Source 14 \\
\end{tabular} & & 0 & & \\
\hline Source 15 & & & 18 & \\
\hline Source 16 & & 0 & & \\
\hline Source 17 & & & 2 & \\
\hline Source 18 & & 2 & & \\
\hline
\end{tabular}

Gambar 5. Hasil running software kombinasi TPA existing dengan TPA usulan II

\section{Analisis menggunakan kombinasi TPA existing dengan TPA usulan I dan II}

Biaya yang dikeluarkan apabila menggunakan kombinasi TPA existing dengan TPA usulan I dan TPA usulan II adalah sebesar Rp.2.121.919,80. Namun terdapat sumber dummy yaitu sampah yang bisa ditampung oleh TPA usulan I sebanyak $128,03 \mathrm{~m}^{3}$ dan bisa ditampung oleh TPA usulan II sebanyak $91 \mathrm{~m}^{3}$ seperti terlihat pada gambar 6 .

\begin{tabular}{|c|c|c|c|}
\hline \multicolumn{2}{|c|}{ Thensportation Shipments } & \multicolumn{2}{|c|}{0 回 $x$} \\
\hline \multicolumn{4}{|c|}{ (untitled) Solution } \\
\hline $\begin{array}{l}\text { Optimal cost = } \\
\text { \$2121920,0 }\end{array}$ & TPA Existing & TPA usulan 1 & TPA usulan 2 \\
\hline Source 1 & & & 6 \\
\hline Source 2 & & & 14 \\
\hline Source 3 & & 9 & \\
\hline Source 4 & & & 49 \\
\hline Source 5 & & & 23 \\
\hline \begin{tabular}{|l|} 
Source 6 \\
\end{tabular} & & & 24 \\
\hline \begin{tabular}{|l|} 
Source 7 \\
\end{tabular} & & 9 & \\
\hline Source 8 & 261 & & \\
\hline Source 9 & 139 & & 131 \\
\hline Source 10 & & & 3 \\
\hline Source 11 & & 118 & \\
\hline Source 12 & & & 28 \\
\hline Source 13 & & 3 & \\
\hline Source 14 & & 0 & \\
\hline Source 15 & & 18 & \\
\hline Source 16 & & 0 & \\
\hline Source 17 & & 2 & \\
\hline Source 18 & & & 2 \\
\hline Dummy & & 128,03 & 91 \\
\hline
\end{tabular}

Gambar 6. Hasil running software kombinasi TPA existing dengan kedua TPA usulan 


\section{Analisis dummy}

Adanya tujuan dummy ketika menggunakan TPA usulan, baik ketika menggunakan TPA usulan I maupun TPA usulan II, menjadi sebuah masalah karena masih ada sampah yang belum bisa terangkut secara keseluruhan. Sumber dummy juga terjadi ketika menggunakan kombinasi TPA existing dengan kedua TPA usulan, hal ini akan terjadi ketidakefisienan dalam penggunaan fasilitas yang ada. Oleh karena itu dengan adanya tujuan dummy dan sumber dummy tersebut, pihak terkait bisa memaksimal TPA existing seperti yang dilakukan saat ini namun dengan risiko dapat mempercepat masa umur pakai nya.

\section{KESIMPULAN DAN SARAN \\ Kesimpulan}

Berdasarkan hasil analisis dalam penelitian ini, kesimpulan yang bisa diambil adalah:

1. Hasil perhitungan solusi optimal tiap lokasi alternatif menggunakan software POM menunjukkan bahwa apabila menggunakan kombinasi TPA existing dengan TPA usulan I total biaya yang dikeluarkan dalam sehari Rp.1.764.105,20. Sementara biaya yang dikeluarkan apabila menggunakan kombinasi TPA existing dengan TPA usulan II adalah sebesar Rp. 1.981.150,60. Dan biaya yang dikeluarkan apabila menggunakan kombinasi TPA existing dengan kedua TPA usulan adalah sebesar Rp.2.121.919,80.

2. Keputusan yang bisa diambil oleh pemangku kepentingan dalam penentuan lokasi alternatif tempat pembuangan akhir sampah adalah kombinasi penggunaan TPA existing dengan TPA usulan I dikarenakan mendapatkan biaya terendah dari semua alternatif. Adanya sumber dummy dan tujuan dummy bisa diselesaikan dengan memaksimal TPA existing seperti yang dilakukan saat ini namun dengan risiko dapat mempercepat masa umur pakai nya.

\section{Saran}

Demi sempurnanya penelitian tentang penentuan lokasi alternatif tempat pembuangan akhir sampah (TPA) ini, peneliti memberikan beberapa saran, diantaranya:

1. Penelitian ini merupakan pengembangan dari teori yang telah dipelajari sebelumnya.
Sebagian besar dari pengolahan data merupakan hasil dari perhitungan secara personal peneliti, penilaian dari setiap orang mungkin akan berbeda.

2. Dalam penelitian ini kapasitas TPA usulan yang digunakan adalah estimasi daya tampung perhari. Penentuan kapasitas TPA usulan bisa menggunakan parameter yang berbeda, misal kapasitas TPA secara keseluruhan (total) tanpa memperhitungkan umur pakai nya.

3. Perlu adanya penelitian berikutnya yang menggunakan atau menggabungkan antara metode kualitatif dengan metode kuantitatif guna mendukung keputusan proses penentuan TPA usulan.

4. Biaya yang diperlukan dalam perhitungan ada baiknya menggunakan semua unsur yang diperlukan dalam menentukan biaya dari sumber ke tujuan.

\section{DAFTAR PUSTAKA}

Fathoni, M. Z. Optimasi kebijakan outsourcing proses kiln dry dengan pendekatan metode transportasi untuk mendukung supply chain (studi kasus: Perusahaan Furniture di Surabaya). MATRIK Vol. 13 No. 2. 2013.

http://gresikkab.go.id/berita/2015_03_05_gand eng_pihak_ketiga_untuk_mengolah_sam pah_gresik, diakses pada 06 Januari 2018

http://gresikkab.go.id/profil/dinas lingkungan hidup, diakses pada 06 Januari 2018

https://www.bangsaonline.com/berita/25097/pe ngelolaan-tempat-sampah-di-kota-gresik, diakses pada 06 Januari 2018.

Hutama, Adi CV. 2017. Jasa Konsultansi Studi revitalisasi TPA Ngipik kabupaten Gresik. Gresik.

LPPM ITS, DLH Kab. Gresik. 2012. Penyusunan Studi kelayakan TPA Kecamatan Wringinanom. p. $47 \& 93$

Mulyono, Sri. 2002. "Riset Operasi", edisi revisi, Fakultas Ekonomi Universitas Indonesia, Jakarta.

Pratiwi, Statiswaty, Tajidun. 2016. Sistem Penunjang Keputusan Penentuan Lokasi Terbaik Pembuangan Sampah Sementara Menggunakan Metode Brown Gibson. Semantik 2 (2) : 125-134.

Tatik Khusniah. 2000. Pendayagunaan Sumber Daya Hayati dalam 
Pengelolaan Lingkungan. Prosiding. Seminar Nasional. Salatiga: Universitas Kristen Satya Wacana.

Taylor III, B.W, 2006. "Sains Management", Edisi Indonesia, Jakarta, Salemba Empat.

Triwira Jasatama, CV. 2013. Studi kelayakan TPA Desa Banyutengah Kecamatan Panceng Kabupaten Gresik. p.47-51

Wignjosoebroto S. 2009. Tata Letak Pabrik dan Pemindahan Bahan. Edisi Keempat. Guna Widya. Surabaya.

Yulipriyanto. 2010. Biologi Tanah dan Strategi Pengelolaannya. Yogyakarta: Graha Ilmu. 